\title{
The Effect of Financial Literacy and Emotions on Intent to Control Personal Budget: A Study among Israeli College Students
}

\author{
Shosh Shahrabani \\ Correspondence: Shosh Shahrabani, Economics and Management Department, The Max Stern Emek Yezreel \\ College, Emek Yezreel 19300, Israel. Tel: 972-4-642-3526. E-mail: shoshs@gmail.com
}

Received: June 13, 2012

Accepted: July 16, 2012

Online Published: August 1, 2012

doi:10.5539/ijef.v4n9p156

URL: http://dx.doi.org/10.5539/ijef.v4n9p156

\begin{abstract}
The current study, carried out in 2010 after the global financial crisis, analyzes the factors affecting intent to control a personal budget among Israeli college students. The results show that intention to budget among students is affected by past debt frequency, level of negative emotions experienced by participants when their bank account was significantly overdrawn, financial literacy level, income and nationality. In addition, the results indicate that positive attitudes toward financial management moderate the negative impact of past debt frequency on the intention to control a personal budget without significant debt. Improving financial literacy and changing attitudes toward financial management can increase budgeting intentions.
\end{abstract}

Keywords: financial literacy, attitudes, budget control, emotions

\section{Introduction}

In the wake of the 2008 global financial crisis, financial literacy and budgetary control seem more important now than ever. The financial crisis highlighted weaknesses and lack of financial knowledge on the part of individuals, which led them to accumulate debts. These circumstances raise the question of whether and to what extent individuals intend to control their budget and avoid accumulating debts, especially after this crisis. Budget control or budgeting can be viewed as a strategy for managing personal finances in order to avoid the negative outcomes of debt accumulation (Lunt \& Livingstone, 1991).

The current study, carried out in 2010 after the global financial crisis, analyzes the factors affecting intent to control a personal budget among Israeli college students. Examining budgeting intentions among students is important since strong evidence indicates that college students do not possess a high degree of financial knowledge (Chen \& Volpe, 1998; Avard et al., 2005; Jones, 2005; Shahrabani, 2012) and that students have increasing debt burdens (e.g., Austin \& Phillips, 2001; Christie \& Munro 2003; Warwick \& Mansfield, 2000). Understanding the factors that influence individuals to maintain a budget may be useful in formulating interventions designed to reduce debt likely to accumulate due to the lack of money management.

Several studies examining budgeting intention and attitudes toward debt among college students were based upon the theory of planned behavior (TPB - Ajzen, 1988, 1991). TPB has a proven record within the field of psychology for predicting the ways in which individuals choose to act (e.g., Andrykowsky, et al. 2005).Within the TPB framework, intention is determined by cognitive evaluations of behavior (i.e., attitudes or opinions), as well as by other factors, such as perceptions of behavioral control. For example, Chudry, et al. (2011) investigated a TPB application that included involvement and decision-making style in predicting students' borrowing attitudes. Their results suggest that students regard themselves as good money managers, but lack control over borrowing and debt. In addition, the authors found that the combination of involvement and decision-making style as a style/involvement variable had a powerful mediating effect in predicting borrowing intention.

The model developed by Kidwell and Turrisi (2004) also examined intention to control a budget by incorporating independent variables affecting this intention from two theories: TPB and theory of social behavior (Triandis, 1977, 1994). The alternative model of social behavior (Triandis, 1977, 1994) incorporates affect, past behavior, social pressure and perceived control in predicting behavior. Their results show that negative affect, attitude, subjective norm, past behavior and moderating influences of perceived control were significant determinants of intention to maintain a financial budget. 
The current study adds to the existing literature by using a modified version of the Kidwell and Turrisi (2004) model that incorporates variables such as attitudes toward money management and past behavior (frequency of being in debt). In addition, the current model includes the following variables: (a) objective financial literacy level of individuals as reflected by a financial knowledge questionnaire, (b) participants' level of negative emotions as experienced when their bank account was significantly overdrawn, and (c) interaction between frequency of being in debt and attitudes toward personal finances, since attitude toward budgeting can moderate past performance. This interaction is important since during the 2008 financial crisis people became more aware of economic and financial issues, partly due to extensive media coverage, so that people may possibly have changed their attitudes toward money management. I am not aware of any studies examining both objective and subjective factors affecting the intention to control a budget after the 2008 financial crisis. The current study fills this void.

\section{The Model}

The main hypotheses with respect to the factors affecting intention to control one's personal budget without debts are the following:

- $\quad$ Financial literacy level: The findings of Hilgert, et al. (2003) show that those who score higher on financial literacy level (henceforth, FL) are more likely to engage in recommended financial practices. Therefore,

$\mathbf{H}_{1}$ : People with high FL scores will exhibit greater intention to control their budget without incurring debt.

- $\quad$ Frequency of being in debt: The theory of social behavior (Triandis 1977, 1994) predicts that behavior is determined by past behavior (habit). In addition, the findings of Kidwell and Turrisi (2004) show that past behavior (frequency of maintaining a budget over six months) is a significant factor affecting budgeting intention. Therefore,

$\mathbf{H}_{2}$ : People who are usually not in debt will exhibit greater intentions to control their own budget, and vice versa.

- $\quad$ Personal finance attitudes: According to the TPB (Ajzen, 1988, 1991), intention is determined, among other things, by cognitive evaluations of behavior (i.e., attitudes). In the current study, the attitude variable include attitudes toward five items: (a) maintaining adequate financial records, (b) spending less than income, (c) maintaining adequate insurance coverage, (d) planning and implementing a regular investment program and (e) avoiding debt accumulation while running a personal budget. Therefore, the hypothesis is:

$\mathbf{H}_{3}$ : Positive attitudes toward budgeting and personal financial management are expected to positively affect intention to control a budget.

- $\quad$ Negative emotion index: The index comprises the level of six negative emotions individuals experienced while their bank account was significantly overdrawn (or how they would feel if they were in such a situation): worried, angry, concerned, fearful, frightened and nervous. According to the feelings-as-information model, feelings or affective states can be perceived as reflections of the environment that signal the individual to respond to situational demands. "Feeling bad" indicates something is wrong in the environment; hence, the individual is alerted to do something about the situation. Cognitive resources will be allocated to seek strategies to deal with the problem, and the person will engage in detail-oriented thinking, i.e., systematic processing (Schwarz, 2000, 2001). Therefore,

$\mathbf{H}_{4}$ : A higher score on the negative emotions index is expected to positively affect intention to control a budget.

\section{Methodology}

\subsection{Procedure}

The study, which was approved by the college's ethic committee, was conducted in 2010 in two public colleges in Israel. The questionnaire survey was distributed among students from various academic fields during class and collected after about 40 minutes. Students were told that the questionnaire was anonymous and would not in any way affect their grades. Students could choose not to fill in the questionnaire, but very few chose not to.

\subsection{Sample}

The study's sample comprised 574 students. Of the students in the sample, $69 \%$ were female and $31 \%$ male, $84 \%$ had grown up in Israel while $16 \%$ were new immigrants. In addition, $86 \%$ of the students in the sample were Jews and $14 \%$ were Arabs and others, and the mean age was 24.6. The students majored in various academic fields ( $49 \%$ from the Economics Department and $51 \%$ from other academic units). In addition, the mean number 
of years of work experience was 2.45 for Jews and 1.75 for Arabs and others. The monthly income of $75.5 \%$ of the participants was below 3,000 NIS, about one third of the average monthly income for employees in Israel.

\subsection{The Questionnaire}

The survey included parts that were based on questionnaires from previous studies (see below). The questionnaire, which was translated into Hebrew by the author and then retranslated into English by an English editor, was retested using a pilot study. The consistency of the survey was further assessed using Cronbach's alpha. The survey questionnaire (see Appendix) included the following parts:

a. Personal finance attitudes: This measure is based on a portion of the Chen and Volpe (1998) questionnaire. Participants were asked to rank their attitude regarding five items, ranging from 1 (very unimportant) to 5 (very important). For example: "How important is it to avoid accumulating debts while running a personal budget?" The personal finance attitudes index was measured as an average level of the responses to the items on the attitude questionnaire.

b. Financial literacy: The survey included a test of knowledge by means of multiple-choice questions based on Chen and Volpe, 1998, questions 12, 30, and on Van Rooij et al., 2011, box1, questions 1-5, and box 2, question 15, which were translated into Hebrew and retested in Shahrabani (2012) (questions 1 and 6 in the questionnaire in Part B of the Appendix). The responses from each participant were used to calculate the mean percentage of correct scores for each question. Consistent with the existing literature (Chen and Volpe, 1998), the mean percentages of correct scores were grouped into: (1) over $80 \%$, representing a relatively high level of knowledge; (2) $60 \%$ to $79 \%$, representing a medium level of knowledge; and (3) below $60 \%$, representing a low level of knowledge. The questions refer to "simple calculations," "compound interest," "inflation," "time value of money", and "money illusion", "saving and borrowing", and "advanced literacy. These questions helped evaluate respondents' knowledge of fundamental economic concepts for making decisions about saving, basic financial transactions, financial planning and knowledge about investment vehicles and knowledge of risk diversification.

c. Negative emotions: Respondents were asked to estimate their level on six negative emotions (worried, angry, concerned, fearful, frightened, and nervous) they experienced when their bank account was significantly overdrawn (or how they would feel if they were in such a situation). This part of the questionnaire is based on the emotions questionnaire of Lerner, et al. (2003), which was translated into Hebrew and retested in Benzion, et al. (2009). The scale of the items ranged from 1 (I did not feel the slightest bit of emotion) to 7 (I felt very strong emotion). The negative emotions index was calculated as the average of each of the six emotion levels combined together (worried, angry, concerned, fearful, frightened, and nervous).

d. Personal details: including demographic and socio-economic details. In addition, participants were asked if they intended to run a personal budget without overdraft (response options ranged from 1 "very much" to 5 "not at all") and how often their bank account is overdrawn (response options ranged from 1 "all the time" to 4 "never").

\section{Results}

\subsection{Results of the Mean Values}

Table 1 summarizes the percentage of participants who have an overdrawn bank account, and the percentage of participants who intend to control their personal budget without debt; in addition, the table shows the mean values and standard deviations (in brackets) on the negative emotions index and the personal finance attitude index. Each of the indexes was measured as an average of responses to all the relevant items on the questionnaire. The Cronbach's alpha values for the negative emotions index and the personal finance attitude index were 0.90 and 0.69 , respectively.

Table 1 shows that more than two-thirds of the sample do not have an overdraft in their bank account most of the time $(69 \%)$, while almost a third part of the sample (31\%) declared their bank account is overdrawn most of the time or always. However, $88 \%$ declared that they intend to control their personal budget without debt.

Table 1 also reveals that the participants have an intermediate level of negative emotions toward being significantly overdrawn in their bank account ( 3.65 out of 7 , where $1=$ felt the emotions very much and $7=$ did not feel the emotion at all). In addition, the high level on the personal finance attitudes index (4.26) indicates that most of the participants in the sample think it is important to avoid incurring debts. 
Table 1. Descriptive statistics

\begin{tabular}{|c|c|c|c|c|c|}
\hline & & & $\begin{array}{l}\mathrm{N} \\
\text { Number of } \\
\text { subjects }\end{array}$ & Percentage distribution & $\begin{array}{l}\text { Mean } \\
(\mathrm{SD})\end{array}$ \\
\hline \multirow[t]{6}{*}{ Financial factors } & $\begin{array}{l}\text { Bank account } \\
\text { overdrawn }\end{array}$ & $\begin{array}{l}\text { Always, or most of the } \\
\text { time }\end{array}$ & 174 & $31 \%$ & \\
\hline & & Never or rarely & 386 & $69 \%$ & \\
\hline & $\begin{array}{l}\text { Intention to control } \\
\text { personal budget }\end{array}$ & Very much & 308 & $56 \%$ & \\
\hline & & To a large extent & 172 & $32 \%$ & \\
\hline & & Moderately & 38 & $7 \%$ & \\
\hline & & Slightly or not at all & 26 & $5 \%$ & \\
\hline $\begin{array}{l}\text { Negative emotions } \\
\text { index* }\end{array}$ & & & 508 & & $3.65(1.65)$ \\
\hline Attitudes index** & & & 538 & & $\begin{array}{l}4.26 \\
(0.63)\end{array}$ \\
\hline
\end{tabular}

The findings of the financial knowledge survey, which were described in Shahrabani (2012) study, show that the mean percentage of correct answers was $55.5 \%$, which represents a low level of knowledge on seven out of nine questions, including the following: "interest rate calculation", "inflation", "saving and borrowing", "time discounting" and "investment vehicles". For the other two questions ("simple math calculations", and "money illusion"), the mean percentage of correct answers was about $65 \%$ representing an intermediate level of knowledge.

\subsection{Results of the Analytical Model}

Using an Ordinal Probit regression, the model describes the factors affecting the intention to control one's current personal budget (i.e., maintain a debt-free budget). The dependent variable was the degree of intention to keep one's budget debt-free (scale ranged from 1- certainly intend to 5- certainly do not intend).

The independent variables included: (a) being frequently in debt (base=frequent debt); (b) negative emotion index (scale ranged from 1 - felt the emotions very much to 7 - I did not feel the emotion at all); (c) financial knowledge: following Chen and Volpe (1998), the participants were classified into two subgroups using the median percentage of the correct answers given by the sample for the knowledge part of survey. Participants with scores higher than the sample median were classified as having relatively more knowledge. Participants with scores equal to or below the median were classified as having relatively less knowledge. The dichotomous variable of financial knowledge was then used in the regression as independent variable $(0=$ low level, $1=$ high level); (d) attitudes toward personal finances: scale ranged from 1 (very unimportant) to 5 (very important); (e) interaction variable between frequency of being in debt and attitudes toward personal finances; (f) socio-demographic variables: age, gender (base=female); nationality (base=non-Jews) and income; (g) department (base $=$ non-economics departments).

In addition, the same regression was used separately for economics students, who are more knowledgeable about financial management than are other students (Shahrabani, 2012), and for non-economics students. Table 2 describes the results of the three regressions (entire sample, economics students, and non-economics students). 
Table 2. Factors affecting intention to control personal budget without debt

\begin{tabular}{|c|c|c|c|}
\hline \multirow{2}{*}{$\begin{array}{l}\text { Dependent variable } \\
\text { Explanatory variables }\end{array}$} & \multicolumn{3}{|c|}{ Intention to control budget without debt ${ }^{1}$} \\
\hline & $\begin{array}{l}\text { Entire sample } \\
(\mathrm{N}=464)\end{array}$ & $\begin{array}{l}\text { Economics Department } \\
\text { students }(\mathrm{N}=249)\end{array}$ & $\begin{array}{l}\text { Students in other } \\
\text { departments } \\
(\mathrm{N}=215) \\
\end{array}$ \\
\hline & Coefficient (Std. Err.) & Coefficient (Std. Err.) & Coefficient (Std. Err.) \\
\hline $\begin{array}{l}\text { Department } \quad \text { (base=non- } \\
\text { Economics department) }\end{array}$ & $\begin{array}{l}-0.04 \\
(0.13)\end{array}$ & - & - \\
\hline Gender $($ base $=$ female $)$ & $\begin{array}{l}-0.13 \\
(0.13)\end{array}$ & $\begin{array}{l}0.17 \\
(0.17)\end{array}$ & $\begin{array}{l}-0.25 \\
(0.26)\end{array}$ \\
\hline Age & $\begin{array}{l}0.03 \\
(0.01)\end{array}$ & $\begin{array}{l}-0.03 \\
(0.04)\end{array}$ & $\begin{array}{l}0.03 \\
(0.02)\end{array}$ \\
\hline $\begin{array}{l}\text { Nationality } \\
\text { (base=non-Jews) }\end{array}$ & $\begin{array}{l}-0.72 * * * \\
(0.16)\end{array}$ & $\begin{array}{l}-0.54 * * \\
(0.24)\end{array}$ & $\begin{array}{l}-0.85 * * * \\
(0.24)\end{array}$ \\
\hline Income & $\begin{array}{l}-0.17 * * \\
(0.07)\end{array}$ & $\begin{array}{l}-0.10 \\
(0.10)\end{array}$ & $\begin{array}{l}-0.22 * * \\
(0.10)\end{array}$ \\
\hline $\begin{array}{l}\text { Frequent debt } \\
\text { (base=frequently in debt) }\end{array}$ & $\begin{array}{l}-2.07 * * \\
(0.88)\end{array}$ & $\begin{array}{l}-3.39 * * \\
(1.46)\end{array}$ & $\begin{array}{l}-1.19 \\
(1.17)\end{array}$ \\
\hline Negative emotion index ${ }^{2}$ & $\begin{array}{l}0.08^{* *} \\
(0.03) \\
\end{array}$ & $\begin{array}{l}-0.01 \\
(0.05) \\
\end{array}$ & $\begin{array}{l}0.18 * * * \\
(0.05)\end{array}$ \\
\hline $\begin{array}{l}\text { Financial knowledge (base } \\
=\text { low level) }\end{array}$ & $\begin{array}{l}-0.29 * * \\
(0.13)\end{array}$ & $\begin{array}{l}-0.21 \\
(0.16) \\
\end{array}$ & $\begin{array}{l}-0.47 \\
(0.25) \\
\end{array}$ \\
\hline Personal finance attitude ${ }^{3}$ & $\begin{array}{l}-0.64 * * * \\
(0.12)\end{array}$ & $\begin{array}{l}-0.77 * * * \\
(0.18)\end{array}$ & $\begin{array}{l}-0.52 * * * \\
(0.18)\end{array}$ \\
\hline $\begin{array}{l}\text { (Finance attitude)X (Frequent } \\
\text { debt) }\end{array}$ & $\begin{array}{l}0.52 * * \\
(0.20) \\
\end{array}$ & $\begin{array}{l}0.83 * * \\
(0.34)\end{array}$ & $\begin{array}{l}0.32 \\
(0.27) \\
\end{array}$ \\
\hline Pseudo $\mathrm{R}^{2}$ & 0.07 & 0.07 & 0.09 \\
\hline $\begin{array}{l}\text { Overall Chi-square } \\
\text { (p value) }\end{array}$ & $\begin{array}{l}70.47 \\
(0.00)\end{array}$ & $\begin{array}{l}34.16 \\
(0.00)\end{array}$ & $\begin{array}{l}44.32 \\
(0.00)\end{array}$ \\
\hline \multicolumn{4}{|c|}{$\begin{array}{l}{ }^{2} \text { scale ranged from } 1 \text { (I felt very strong emotion), to } 7 \text { (I did not feel the slightest bit of emotion. } \\
{ }^{3} \text { Scale ranged from } 1 \text { (very unimportant) to } 5 \text { (very important) }\end{array}$} \\
\hline
\end{tabular}

The results of the separate regression for the Economics Department students (column 3) show that the intention to control personal debt is positively affected by a lower frequency of being in debt in one's current account and a higher level of positive personal finance attitude. In addition, the interaction variable between frequency of being in debt and attitudes was significant, indicating that attitude toward budgeting can moderate past performance or habit of being frequently in debt with respect to an individual's intention to control self-budget. For example, students who are frequently in debt but also have a positive attitude toward financial management intend to control their own budgets.

The findings of the separate regression for the students who were not in the Economics Department (column 4) show that the intention to control personal debt is positively affected by higher income levels, a higher level on the negative emotion index regarding the possibility of having a large debt in current account, and a higher level of positive personal finance attitude.

The results in Table 2 for the entire sample (column 2) indicate that all the model's hypothesized variables for the intention to control personal budget contributed significantly to prediction, with the exception of age and gender, thus providing support for Hypotheses $\mathrm{H}_{1}-\mathrm{H}_{4}$. More specifically, the results reveal that the significant factors positively affecting intention to control personal budget without debt include: (a) lower frequency of being in debt in current account (b) higher level of positive personal finance attitude; (c) higher level of negative emotion index toward possibility of having a large debt in current account; (d) higher level of financial knowledge; and (e) higher levels of income. 
In addition, the interaction variable between frequency of being in debt and attitudes was significant, indicating that attitude toward budgeting and financial management can moderate past performance or habit of being frequently in debt with respect to an individual's intention to control his/her budget.

Finally, for the entire sample and for each group separately, Jews were found to have greater intentions to control personal debt in comparison to non-Jews.

\section{Discussion}

The current study, carried out in 2010 after the 2008 global financial crisis, examined the objective and subjective factors affecting intentions to control one's personal budget without debt among Israeli college students.

The findings of the analytical model for the entire sample indicate that the significant factors positively affecting budgeting intention include past behavior of being less frequently in debt in one's current account and a higher score on the negative emotion index regarding the possibility of having a large debt in one's current account. Moreover, a higher positive attitude toward budgeting and personal financial management, a higher level of financial knowledge and higher income levels were also found to positively affect intention to control one's personal budget. Kidwell and Turrisi (2004) also found that negative affect, attitude, and past behavior were significant determinants of intention to maintain a financial budget.

In addition, the current study's findings indicate that attitude toward budgeting and financial management moderates the impact of past performance (being frequently in debt) on an individual's intention to control his/her budget. After the 2008 financial crisis, people may possibly have changed their attitudes toward financial management and are now more aware of the negative consequences of large debts. Therefore, their positive attitude moderates the impact of past frequent debt on the intention to control their budget.

The results of this model emphasize the importance of attitudes, not only toward budgeting, as was found in Kidwell and Turrisi (2004) study, but also toward financial management in general, including maintaining adequate financial records, spending less than one's income, maintaining adequate insurance coverage, planning and implementing a regular investment program and avoiding accumulating debts while running a personal budget. The findings also reveal that Jews have greater intentions to control personal debt in comparison to non-Jews, supporting the results of previous studies with respect to the financial knowledge gaps between Jewish and non-Jewish students (Shahrabani, 2012).

The results of this study indicate that a change in budgeting intention may require acquiring more knowledge about money management and financial debt and, in addition, changing attitudes toward money management. This is especially important for young people, since financial skills constitute an essential basis for avoiding and solving financial problems and for planning their future. Moreover, maintaining a budget may reduce negative feelings of anxiety, stress and fear associated with the consequences of financial debt. Future studies are needed to examine how well these findings generalize to non-college populations.

\section{Acknowledgements}

The financial support of the Max Stern Emek Yezreel College is gratefully acknowledged. I would like to thank Ilya Novikov for statistical analysis and Maya Uliel for her valuable assistance in data collection.

\section{References}

Ajzen, I. (1988). Attitudes, personality and behavior. Milton Keynes, UK: Open University Press.

Ajzen, I. (1991). The theory of planned behavior. Organizational Behavior and Human Decision Processes, 50, 179-211. http://dx.doi.org/10.1016/0749-5978(91)90020-T

Andrykowsky, M., Beacham, A., Schmidt, J., \& Harper, F. (2005). Application of the theory of planned behavior to understand intention to engage in physical and psychological health behavior after cancer diagnosis. Psycho-Oncology, 15, 759-771. http://dx.doi.org/10.1002/pon.1007

Austin, M., \& Phillips, M. (2001). Educating students: An ethics responsibility of credit card companies. Journal of Services Marketing, 15, 516-528. http://dx.doi.org/10.1108/EUM0000000006209

Avard, S., Manton, E., English, D., \& Walker, J. (2005). The financial knowledge of college freshmen. College Student Journal, 39(2), 321-338.

Bajtelsmit, V.L., Bernasek, A., \& Jianakoplos, N.A. (1999). Gender differences in defined contribution decisions. Financial Services Review, 8(1), 1-10. http://dx.doi.org/10.1016/S1057-0810(99)00030-X 
Benzion, U., Shahrabani, S., \& Shavit, T. (2009). Emotions and perceived risks after the 2006 Israel-Lebanon war. Mind \& Society, 8, 21-41. http://dx.doi.org/10.1007/s11299-008-0048-8

Chen, H., \& Volpe, R. P. (1998). An analysis of personal financial literacy among college students. Financial Services Review, 7(2), 107-128. http://dx.doi.org/10.1016/S1057-0810(99)80006-7

Christie, H., \& Munro, M. (2003). The logic of loans: Students' perceptions of the costs and benefits of the student loan. British Journal of Sociology of Education, 24, 621-636. http://dx.doi.org/10.1080/0142569032000127170

Chudry, F., Foxall, G. \& Pallister, J. (2011). Exploring attitudes and predicting intentions: Profiling student debtors using an extended theory of planned behavior. Journal of Applied Social Psychology, 41, 119-149. http://dx.doi.org/10.1111/j.1559-1816.2010.00705.x

Hilgert, M. A., Hogarth, J. M., \& Beverly, S. G. (2003). Household financial management: the connection between knowledge and behavior. Federal Reserve Bulletin, 309-322.

Jones, J. E. (2005). College students' knowledge and use of credit. Financial Counseling and Planning, 16, 9-16. http://dx.doi.org/10.1016/S0167-4870(03)00073-4

Kidwell, B., \& Turrisi, R. (2004). An examination of college student money management tendencies. Journal of Economic Psychology, 25, 601-616.

Lerner, J. S., Gonzalez, R. M., Small, D. A., \& Fischhoff, B. (2003). Emotion and perceived risks of terrorism: A national field experiment. Psychological Science, 14, 144-150. http://dx.doi.org/10.1111/1467-9280.01433

Lunt, P. K., \& Livingstone, S. M. (1991). Everyday explanations for personal debt: A network approach. British Journal of Social Psychology, 30, 309-323. http://dx.doi.org/10.1111/j.2044-8309.1991.tb00948.x

Lusardi, A., Mitchell, O. S., \& Curto, V. (2010). Financial Literacy among the Young. Journal of Consumer Affairs, 44, 358-380. http://dx.doi.org/10.1111/j.1745-6606.2010.01173.x

Schwarz, N. (2000). Emotion, cognition, and decision making. Cognition and Emotion, 14(4), 433-440. http://dx.doi.org/10.1080/026999300402745

Schwarz, N. (2001). Feelings as information: Implications for affective influences on information processing. In L. L. Martin, \& G. L. Clore (Eds.), Theories of mood and cognition: A user's guidebook, 159-176. Mahwah, NJ: Lawrence Erlbaum Associates, Publishers.

Shahrabani S. (2012). Financial Literacy among Israeli College Students. The Journal of College Student Development. forthcoming.

Triandis, H. C. (1977). Interpersonal behavior. Monterey, CA:Brooks/Cole.

Triandis, H. C. (1994). Culture and social behavior. New York: McGraw-Hill.

Van Rooij, M., Lusardi, A., \& Alessi, R. (2011). Financial literacy and stock market participation. Journal of Financial Economics, 101(1), 449-472. http://dx.doi.org/10.1016/j.jfineco.2011.03.006

Warwick, J., \& Mansfield, P. (2000). Credit card consumers: College students' knowledge and attitude. Journal of Consumer Marketing, 17, 617-626. http://dx.doi.org/10.1108/07363760010357813

\section{Appendix: The Questionnaire}

\section{Survey of attitudes and knowledge about personal financial matters}

\section{Part A: Personal details questionnaire}

Age, gender, religion, marital status, immigration year, work experience (years), education, taking a course related to economics and financial terms, monthly income, having a loan or a mortgage (yes/no), intention to run a personal budget without overdraft (scale response options ranged from 1 "very much" to 5 "not at all"), how often is your bank account overdrawn? (response options ranged from 1 "all the time" to 4 "never").

\section{Part B: Financial literacy}

1. Savings and borrowing knowledge:

Which of the following investments requires that you keep your money invested for a specified period or pay an early withdrawal penalty: (a) certificate of deposit, (b) checking account that pays interest, (c) government savings bond, (d) money market mutual fund, (e) do not know. 


\section{Money illusions}

Suppose that in 2010, your income has doubled and the prices of all goods have also doubled. In 2010, how much will you be able to buy with your income? (a) More than today; (b) The same; (c) Less than today; (d) Do not know.

\section{Basic calculation}

Suppose you invest 1,000 NIS in a stock for a period of two years. The stock price fell by $40 \%$ after the first year and then increased by $40 \%$ in the second year. In this case after two years: (a) you lost money on the stock, (b) you earned money on the stock, (c) no loss and no gain, (d) do not know.

\section{Time value of money}

Assume a friend inherits 10,000 NIS today and his sibling inherits 10,000 NIS three years from now. Who is richer because of the inheritance? (a) My friend; (b) His sibling; (c) They are equally rich; (d) Do not know.

\section{Interest compounding}

Suppose you had 100 NIS in a savings account and the interest rate was $2 \%$ per year. After five years, how much do you think you would have in the account if you left the money to grow: (a) more than 110, (b) exactly 110, (c) less than 110, (d) Do not know.

\section{Advanced Literacy Questions (investments knowledge)}

Which of the following is FALSE? (a) As shareholder of a mutual fund, you have a right to tell fund managers what securities to buy; (b) A mutual fund is a diversified collection of securities used as an investment vehicle; (c)A mutual fund is an investment corporation that raises funds from investors and purchases securities; (d) Your ownership in a mutual fund is proportional to the number of shares you own in the fund; (e) Do not know.

\section{Advanced Literacy Questions}

Do you think that the following statement is true or false: "Buying a single company stock usually provides a safer return than a mutual fund stock." True/False/Do not know.

\section{Inflation:}

Imagine that the interest rate on your savings account is $2 \%$ per year and inflation is $4 \%$ per year. After one year, how much would you be able to buy with the money in this account? (a) More than today; (b) Exactly the same; (c) Less than today; (d) Do not know.

\section{Interest rate calculation}

Suppose you are considering buying a refrigerator that costs 10,000 NIS today. You can pay in one of the following two forms: (1) three equal monthly payments, or (2) paying 8,100 NIS in cash. Assuming the annual interest rate on bank loans is $10 \%$, which payment option do you think is preferable? (a) three equal payments; (b) cash; (c) there is no difference between the two options; (d) do not know.

\section{Part C: Personal finance attitudes}

Rank the importance of the following items on a scale ranging from 1 (very unimportant) to 5 (very important):

1. Maintaining adequate financial records.

2. Spending less than your income.

3. Maintaining adequate insurance coverage.

4. Planning and implementing a regular investment program.

5. Avoid accumulating debts, while running a personal budget

Part D: Emotions felt while bank account is significantly overdrawn

Rank your feelings during the days your bank account is significantly overdrawn (or your feelings if you were in such a situation) on a scale ranging from 1 (I feel the emotion strongly) to 7 (I did not feel the slightest bit of emotion):

1. Worried; 2. Angry; 3. Concerned; 4. Fearful; 5. Frightened; 6. Nervous. 